\begin{tabular}{|c|c|}
\hline 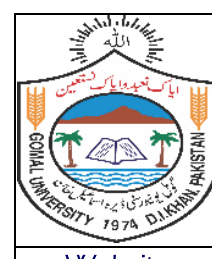 & 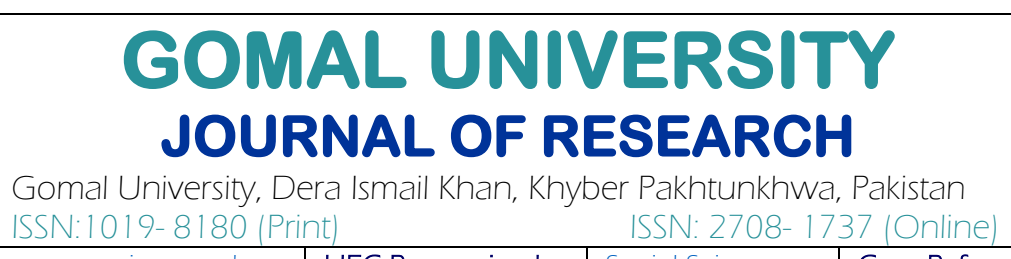 \\
\hline & \begin{tabular}{c|c|c|c|} 
cial Sciences & CrossRef \\
\end{tabular} \\
\hline
\end{tabular}

\title{
NEXUSES OF ETHICAL LEADERSHIP, JOB SATISFACTION AND JOB PERFORMANCE IN ACADEMIA OF KHYBER PAKHTUNKHWA PAKISTAN
}

\author{
Anwar Khan', Muhammad Anwar Khan² \& Sajjad Ahmad Jan³ \\ 'Department of Management Science, Khushal Khan Khattak University, Karak, Pakistan \\ 2Department of Media Studies, Khushal Khan Khattak University, Karak, KPK, Pakistan \\ 3PhD Scholar, Sarhad University of Science and Information Technology, Peshawar
}

\begin{tabular}{|c|c|}
\hline KEYWORDS & 3SIRACI \\
\hline$=$ & \multirow{3}{*}{$\begin{array}{l}\text { Nowadays universities are going through the transition due which new } \\
\text { performance standards have been created. In such situation, performance } \\
\text { of employees can be enhanced through effective ethical leadership. The } \\
\text { current study has examined the dynamic links between job satisfaction, job } \\
\text { performance and ethical leadership in the academia of Pakistan. Using a } \\
\text { cross sectional design, quantitative data were collected from } 150 \text { academic } \\
\text { staff working in three universities. Data were analyzed both by descriptive } \\
\text { and inferential statistics. The results showed that four characteristics, i.e., } \\
\text { practicing preacher; safe haven creator; moral motivator and ethical justice } \\
\text { were positively associated with job performance, whereas this link was } \\
\text { partially mediated by job satisfaction. The results obtained were in a strong } \\
\text { concurrence with the existing literature. Hence, universities of Pakistan } \\
\text { should focus on developing ethical leadership among their employees. In } \\
\text { this way, universities can grow and contribute towards the socioeconomic } \\
\text { development of Pakistan. } \\
\text { c) }\end{array}$} \\
\hline & \\
\hline  & \\
\hline & \\
\hline & \\
\hline
\end{tabular}

\section{INTRODUCTION}

21st century has globally brought paradigm shift in universities around the world (Mohrman, Ma \& Baker, 2008). Days are gone when university teaching was thought to be the tension free occupation (Meng \& Wang, 2019). Universities have now experienced a transition, which has created high performance standards (Khan \& Anwar, 2021). Resultantly universities are getting conscious about its outcomes by thinking about how to ensure high job performance of its employees, since it is critical to the success of universities (Manzoor, Wei, Bányai, Nurunnabi, \& Subhan, 2019). The need for matching pace with the prevalent performance standards has further increased due to advent of COVID-19 pandemic, which has really change the working 
lives inside universities (Anwar, Khan, \& Sultan, 2020). The outcomes of universities can be enhanced over positive behaviors that are adopted by leaders inside universities (Alonderiene \& Majauskaite, 2016). Due to such importance of the leadership and job performance, it is of a great interest to both researchers and practitioners (Dinh et al., 2014). Findings from previous research indicates that ethical leaders can influence the behavior of their employees in positive direction, by building their character and modify their personality (Zhu, Treviño, \& Zheng, 2016).

Previous research studies, like Kinsambwe, (2016), Karuhanga (2015) and Ofoegbu and Alonge (2017) further shows that the organizational outcomes for example job performance, and job satisfaction of the universities can be boost up with the help of ethical leadership styles, which most influential style. For this reason authors like Obicci (2015), Kelidbari, Fadaei and Ebrahimi, (2016) and Khokhar and Rehman (2017) have recommended that researchers should examine the positive impacts of moral leadership on job performance and satisfaction (organizational outcomes) in higher education sector around the world. The dynamic interconnection between the concepts of ethical leadership and the resultant organizational outcomes is not that much simple since it includes both direct as well as indirect effects. For instance, ethical leadership does not affect the performance directly rather than there is indirect factor of job satisfaction, which mediate this relationship (Shafique, Kalyar, \& Ahmad, 2018). For this reason previous studies, like Yuan, Tan, Huang, and Zou (2014), Shafique et al. (2018) and Işik (2020) have strongly suggested that future researchers should examine meditating effect of job satisfaction. In this way, the researchers can understand both direct as well as indirect link between the two variables.

To comprehend the nexus between ethical leadership, job performance and satisfaction in the universities of Pakistan, we need to initially understand dynamics of Higher Education sector in Pakistan. The Higher Education Institutions in Pakistan are divided into public and private. In the initial years, the higher education sector of Pakistan was mostly dominated by the public sector universities, however, after the creation of Higher Education Commission of Pakistan in the year 2002, private sector universities also started to develop rapidly and Higher Education Commission of Pakistan allocated funds for the private sector universities (Halai, 2013). Now the Government of Pakistan is encouraging higher education sector in Pakistan to make liaison with the industry for engaging in the Research and Development related activities, which will ultimately enable Pakistani universities to participate in the national development. In order to know results of government efforts for improving higher education sector of Pakistan, different evaluation studies need to be conducted by independent researchers (Qazi, Raza, Jawaid \& Karim, 2018).

The results of these studies can tell us about the factors that have profound effect of overall performance and productivity of the universities (Asrar-ul-Haq \& Kuchinke, 2016). If we look at existing published literature, then we can trace research studies, e.g., Okan and Akyüz (2015), Barnett (2017), Adeoye (2020) and Grobler and Grobler (2021) on positive effects of the ethical leadership in the academia of western countries (or countries other than Pakistan). In Pakistani context, few studies have been conducted, Torlak and Kuzey (2019) did research on linkages between ethical leadership and job performance in private universities of Pakistan: and more recently Zamin and Hussin, (2021) and Sabir (2021) have conducted research on ethical leadership and it link with the commitment and job performance in the different universities of Pakistan. However, there is an overall lack of empirical research on the said topic in the universities of 
Pakistan. Moreover, the theoretical models on ethical leadership, employees' satisfaction and performance have not been widely tested in Pakistan. Thus, it indicates a serious research gap, which needs to be filled. Keeping in view the importance of this topic, the current study aims at examining the dynamic connection between the positive effects of the ethical leadership and the performance of employees in the academia of Pakistan, through the mediating role of the job satisfaction.

\section{LITERATURE REVIEW}

Ethical leaders have the qualities of honesty and fairness with organization, care and respect for employees and goal orientation with ethical courage (Shakeel, Kruyen, \& Van Thiel, 2019). Good ethical leadership practices are vital to success of any organization, since ethical leaders acts as notion of trust in organization by letting the employees feel that someone is taking care of them (Zaim, Demir, \& Budur, 2021). It motivates the employees to work harder for development of organization. Whereas good organization can keep its employees satisfied by instilling high work performance inside them (Sendjaya, Pekerti, Cooper, \& Zhu, 2019). For this drive, it is thought that employees work related performance is outcome of many factors, including the motivation given by a good leader, the degree of employees' satisfaction with assigned job and the overall conducive but challenging working environment (Cleveland, Huebner, Anderson \& Agbeke, 2019). The Higher Education Sector in Pakistan is growing rapidly and it has been divided into public and private universities. Initially back in 1990s, higher education of Pakistan was mostly dominated by the public sector universities, however, once the higher education commission of Pakistan was established in 2002, private sector universities started to develop rapidly and even higher education commission of Pakistan allocated funds for private sector universities (Halai, 2013).

To comprehend the nature of ethical leadership, job satisfaction and work performance, it is imperative to review the existing theoretical models on such concepts. The ethical leadership can be understood from the three broad approaches, i.e., the utilitarian approach that states that ethical leader maximizes welfare of all employees (Udofia \& Alexander, 2017); libertarianism approach that states that ethical leaders protect the rights and freedoms of employee (Read, 2018); and finally the deontological approach states that ethical leaders should do right things (Dion, 2012). Thus, other approaches are the justice approach (Koopman, Scott, Matta, Conlon, \& Dennerlein, 2019); servant leadership, shared leadership and authentic leadership approaches (Avolio, Walumbwa, \& Weber, 2009). On other side, the popular approaches to job satisfaction includes affect theory of job satisfaction (Tomkins, 1984), the equity theory of job satisfaction (Huseman, Hatfield \& Miles, 1987) and two factors theory of job satisfaction (Herzberg, Mausner \& Snyderman, 1993). In this connection, the job performance can be understood by in-role/ out-role job performance model (Campbell, 1990), the organizational citizenship behavior model (Smith, Organ, \& Near, 1983) in addition to the heuristic conceptual model (Koopmans et al., 2011).

The review of theoretical models can provide valuable insights about the linkages between the concepts of leadership, satisfaction and performance. For review of theoretical models we can derive certain characteristics of ethical leadership, like e.g., ethical insights of organization, fair treatment of workers, role model for others, considering ethics important, good communicators, empathetic and holding self and others for unethical actions (O'Connell \& Bligh, 2009). Also, there are sure characteristics of satisfied employees including happiness with salary, contended 
with working environment, satisfied with boss behavior, sure about job security and happily meeting new challenges (Blanz, 2017). These underlying features of the ethical leadership and employee satisfaction make a strong match with each other. In this regard Yang and Wei (2018) have explained that ethical leaders take care of the employee's needs, that is why they receive positive response from employees. It motivates the employees to work harder for development of organization. However, good organization can keep its employees satisfied by instilling high work performance. Similarly, Brown, Treviño and Harrison (2005) found that employees feel satisfied with those ethical leaders who disciplines wrong-doers, and treats right-doers fairly and respectfully. In this manner, the ethical leaders is predictable to built the trust among employees and trustworthy employees are those who are highly satisfied from work (Mozumder, 2018).

The ethical leader always tries to keep employees happy and satisfied. Based on such nexus, the current study hypothesizes that "H1: The ethical leadership will have a positive influence on the employees' Job Satisfaction in Universities of Pakistan”. The review of theoretical models also gives insights about linkages amid concepts of ethical leadership and job related performance. Since, ethical leaders also work fairly, and honestly which makes them trust worthy road models for employees (Malik, Awais, Timsal, \& Qureshi, 2011). Moreover, ethical leaders work hard, and they communicate importance of hardworking, thus becoming heuristic model of hardworking (Amos, Zhang, \& Read, 2020). Apart from this employees also feel their leaders have best interest all employees, therefore, employees in return work harder (Zhang, Zhong \& Ozer, 2020). In this way the employees can learn so many positive behaviors from their ethical leaders and such positive behaviors helps in instilling a positive work performance attitude (Liu, Kwan, Fu, \& Mao, 2013). It motivates employees to work harder for development of organization whereas good organization can keep its employees satisfied by instilling high work performance in diverse contexts. Based on such strong linkages, this study further hypothesizes that "H2: The ethical leadership will have a positive influence on the employees' job performance in the universities of Pakistan”.

As discussed earlier, the connection amid the concept of the ethical leadership and work related performance is not that much simple since it includes both direct as well as indirect effects. For e.g., ethical leadership doesn't affect the performance directly rather than there is an indirect factor of job satisfaction, which mediate this relationship (Shafique et al., 2018). It is because satisfied employees always put energy toward enhancement of their job performance, however, since employee's satisfaction is dependent on ethical leadership of boss, therefore, employee's satisfaction actually mediate this effects of ethical leadership over job performance (Rizwan, Zeeshan, \& Mahmood, 2017). Thus, this study finally hypothesizes that "H3: Job Satisfaction will mediate (fully or partially) the link amid the concepts of ethical leadership and job related performance of employees working in universities of Pakistan”. Previously mentioned theoretical backgrounds and the detailed discussion on the nature and relationship of the concepts of the ethical leadership, job satisfaction and work performance have helped us in the construction of a research framework for the current study. The research framework has three parts as seen in the Figure 01. The first part is indicating the independent variable of ethical leadership and its four sub dimensions. The second part is indicating the dependent variable of job performance and its two sub dimensions. Finally, the third part is indicating the mediating variable of job satisfaction. 
Figure 1

Research Framework of Study

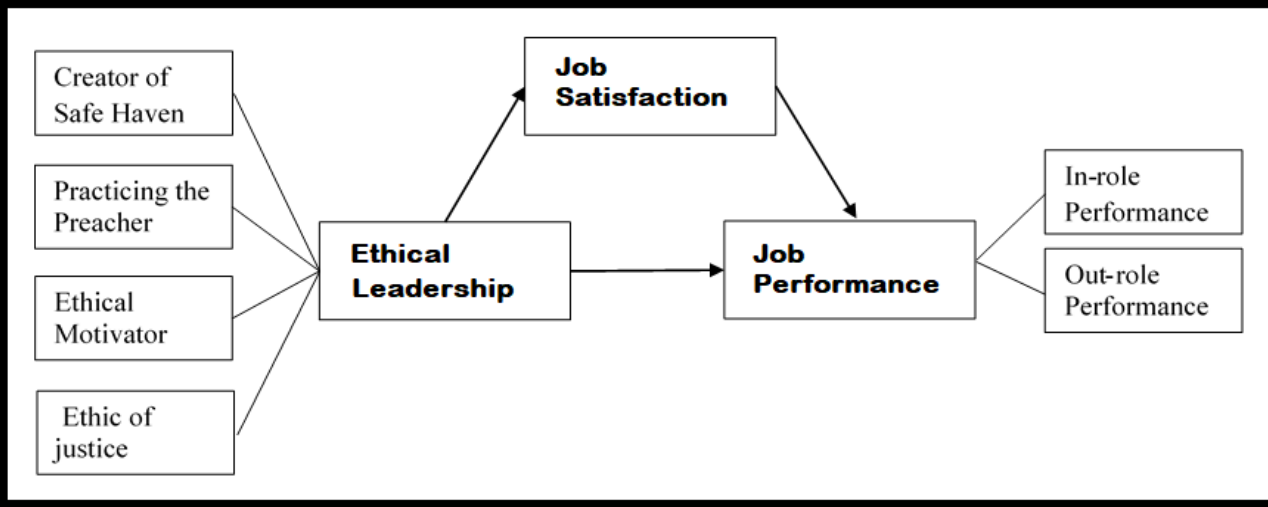

\section{RESEARCH METHODOLOGY}

A cross sectional research design has been adopted, since it will help in conducting research one single point of time, thus, a cross sectional research design is more cost and time effective as compared to the longitudinal research design (Lavrakas, 2008). Since the data was collected through an online self-administered questionnaire, therefore, the quantitative paradigm has been chosen, which focuses on figures and numerical data (Djafar, Yunus, Pomalato, \& Rasid, 2021).

\section{Population \& Sampling}

The population of the current study is academic staff who are working in the three universities of southern Khyber Pakhtunkhwa, Pakistan. As clear from table 01, there were 441 academic staff in the selected three universities. Since it was not practically possible to collect data from whole population (due to time \& cost limits), later, sample was drawn from the total population through a multi stage sampling process. In the first step the whole population was divided into three clusters and then in the second stage, strata were made on the basis of job positions held by the academic staff within the each cluster. In the final step a simple random sampling was done within the arch stratum, and in this way a sample of 251 was obtained as clear from table 01.

Table 1

Population and Sample of Study

\begin{tabular}{|c|c|c|c|c|c|c|c|c|}
\hline \multirow[t]{3}{*}{ Universities (Clusters) } & \multicolumn{8}{|c|}{ Strata } \\
\hline & \multicolumn{2}{|c|}{ Lecturer } & \multicolumn{2}{|c|}{$\begin{array}{l}\text { Assistant } \\
\text { professor }\end{array}$} & \multicolumn{2}{|c|}{$\begin{array}{l}\text { Associate } \\
\text { Professor }\end{array}$} & \multicolumn{2}{|c|}{ Professor } \\
\hline & $\mathrm{N}$ & $\mathrm{n}$ & $\mathrm{N}$ & $\mathrm{n}$ & $\mathrm{N}$ & $\mathrm{n}$ & $\mathrm{N}$ & $\mathrm{n}$ \\
\hline Khushal Khan Khattak University, Karak & 34 & 25 & 19 & 15 & 00 & 00 & 01 & 01 \\
\hline Gomal University, D.I.Khan & 98 & 49 & 113 & 53 & 09 & 04 & 30 & 22 \\
\hline University of Science, Technology Bannu & 71 & 42 & 56 & 35 & 05 & 03 & 05 & 02 \\
\hline Total & 203 & 116 & 188 & 103 & 14 & 07 & 36 & 25 \\
\hline
\end{tabular}




\section{Data Collection}

Data were collected from the academic staff through an online self-administered questionnaire. In this connection, the questionnaire comprised the following sections as described in different section:

1. The first section was about the socio-demographic profile of the respondents and data was collected about the variables like age, gender, marital status, education and job position.

2. The second section was about ethical leadership dimensions. It was measured by the 12 items of the ethical leadership statements developed by Heres (2014) and 05 items of Ethical Leadership Questionnaire developed by (Langlois, Lapointe, Valois, \& Leeuw, 2014).

3. The third section of questionnaire was about job satisfaction and it was assessed by the o6 items of global scale of job satisfaction, developed by Yuan et al., (2014) and o6 items of the job satisfaction scale, as developed by Körner, Wirtz, Bengel, and Göritz (2015).

4. The final section of the questionnaire was about job performance, and it was measured by the 06 items of job performance scale, developed by Goodman and Svyantek (1999) and 06 items of the work performance scale, as developed by Williams and Anderson (1991).

\section{Data Analysis}

Descriptive statistical techniques were applied to analyze demographic data. Data Reliability was determined by calculating the Cronbach's Alpha Coefficients. On other side, the inferential statistics include a series of Confirmatory Factor Analyses, which were run for determining the construct validity of collected data. Moreover, Structural Equation Modeling was performed to examine the direct relationship between the ethical leadership and job performance as well as to know indirect (mediating) relationship between the ethical leadership and job performance via through job satisfaction. Before performing Structural Equation Modeling, the model fit was determined by calculating fit indices like Chi-square $\left(\chi^{2}\right)$, Normed Chi-square $\left(\chi^{2} / \mathrm{df}\right)$, Tucker-Lewis index (TLI), Normed Fit Index (NFI), Root Mean Square Error of Approximation (RMSEA), Root Mean Square Residual (RMR), Goodness of Fit Index (GFI), and Comparative Fit Index (CFI). For the latent variable of ethical leadership, the Structural Equation Model consisted of four indicators, whereas for the latent variable of job satisfaction a single indicator chosen.

Finally, for latent variable of job performance, two factor model was chosen. To test hypotheses, the Structural Equation Modeling method suggested by Holmbeck (1997) was followed. This approach states that at beginning there should be adequate model fit among the independent variable (A), mediator variable (B) and dependent variable (C). In next stage, there should be a direct path between A-C, A-B and B-C. For testing mediation, the A-B (relationship between independent and dependent variables) path should be constrained to zero, and improvement in model fit and path significance should be examined, since if there is no improvements in the fit indices of forced model following inclusion of direct $\mathrm{A}-\mathrm{C}$ path, then there is full mediation. In contrast, if improvements occur in fit indices of constrained model along with significant paths following the inclusion of direct A-C path, then there is a partial mediation. Improvement in fit indices is assessed through examination of the significance levels and changes in Chi Square values. 


\section{RESULTS OF STUDY}

Before data analysis, raw data was examined for any missing data and violation of assumptions of multivariate analysis. Following the preliminary examination, it was found that out of 251 distributed questionnaires, 186 questionnaires were usable. Usability criteria were developed according to guidelines provided by Hair et al. (2010). These guidelines states that the missing data per each case (questionnaire) may be within range of $01 \%$ (minimum) to $11 \%$ (maximum). However, if the missing data per each case (questionnaire) exceed the limit of $11 \%$, then such case (questionnaire) should be discarded. Data obtained from 186 cases were checked for the assumptions of multivariate analysis and no violation of assumption of multivariate analysis was found.

\section{Socio-Demographic Characteristics}

The socio-demographic characteristics of academic staff revealed that overall there were more male teachers as compare to female teachers, as clear from table 02, most probably because in the Khyber Pakhtunkhwa province of Pakistan mostly the male members of the family work and female members mostly work inside their homes. Marital Status wise, most of the teachers (60\%) are married. In this connection, teaching staff within the Pakistani universities is hired after the age of 25, especially after they have completed their Post Graduate studies, therefore, in such age, mostly teacher have already got married. In this regard, moreover, the marriage can act as strong source of social support, therefore, those employees who are married have more satisfied family life and in this way they can have better work-family life balance, which off course has the positive effects on the job performance of such employees (Torlak \& Kuzey, 2019).

Age wise, most of the teachers (65\%) exists in age category of 26 to 35 years, while the rest of the teachers are within the age category of 36 to 50 years. Such age distribution is because most of the seniority level of teachers within the university, also clear from their job positions, the majority of them (75\%) hold either job positions like lecturers or assistant professors, and a less number (25\%) of teachers holds positions like associate and full professors. The age has a unique relationship with working performance and it is believed that employee are energetic in their young age, however, with age, the job maturity and skills could be acquired, therefore, it is expected that senior employees will perform more better since they possess more knowledge, experience and overall maturity in career (Cleveland et al., 2019). Finally, most of teachers have either masters or doctorate degree and few of them have post doctorate. In Pakistan the recent trends show that majority of academic staff are holding PhD degrees. The formal education has direct link with performance and it is believed that those employees who have more education qualification are in better position to perform well within organizations (Hidayat \& Budiatma, 2018).

Table 2

Socio-Demographic Characteristics of Academic Staff

\begin{tabular}{|c|c|}
\hline Socio-Demographic Characteristics & Number (\%) \\
\hline Gender & \\
\hline Male Teachers & $115(61.80 \%)$ \\
\hline Female Teachers & $71(38.20 \%)$ \\
\hline
\end{tabular}




\begin{tabular}{llc} 
& Married Teachers & $112(60.20 \%)$ \\
Age & Unmarried Teachers & $74(39.08 \%)$ \\
& & \\
20 to 25 years & $08(4.30 \%)$ \\
26 to 30 years & $73(39.20 \%)$ \\
31 to 35 years & $48(25.80 \%)$ \\
36 to 40 years & $27(14.50 \%)$ \\
41 to 50 years & $20(10.80 \%)$ \\
$\quad$ Above 50 years & $10(5.40 \%)$ \\
Education $\quad$ & $94(50.54 \%)$ \\
Masters & $82(44.10 \%)$ \\
Doctorate & $10(5.36 \%)$ \\
Pobt Doctorate Positions & $81(43.55 \%)$ \\
Lecturers & $58(31.19 \%)$ \\
Assistant Professors & $32(17.20 \%)$ \\
Associate Professors & $15(8.06 \%)$ \\
\hline
\end{tabular}

\section{Reliability Analysis}

Cronbach's Alpha Coefficients were calculated for determining the Reliability of collected data. The Cronbach's Alpha Coefficients should be above the 0.50 for demonstrating that all of the variables are possessing internal consistency (Gliem \& Gliem, 2003). The results for reliability are given in the table 03, showing that all of variables have Cronbach's Alpha Coefficients above 0.50 .

Table 3

Reliability Analysis of Data

\begin{tabular}{lc}
\hline Variables & Cronbach's Alphas \\
\hline Task Performance & 0.86 \\
Contextual Performance & 0.90 \\
Job Satisfaction & 0.91 \\
Ethic of justice & 0.86 \\
Moral Motivator & 0.82 \\
Practicing Preacher & 0.76 \\
\hline Safe Haven Creator & 0.77 \\
\hline
\end{tabular}

\section{Examining Model Fit}

A series of Confirmatory Factor Analyses were run to examine the model fit. In this regard, the model fit indices were calculated. Table 04 shows that the fit indices for the first model for the latent variable of ethical leadership had four factors and all of its fit indices were within the acceptable range. Next was mediating variable of job satisfaction, which had one factor and all of its fit indices were within acceptable range. Finally the latent variable of job performance, which had two factors, and all of its fit indices were within acceptable range, as clear from table 04 . 


\section{Table 4}

Examination of the Model Fit Indices

\begin{tabular}{lllllllll}
\hline Variables & Models & X2 & df & X2/df & RMSEA & RMR & CFI & GFI \\
\hline Ethical Leadership & Four Factors Model & 3.22 & 02 & 1.62 & 0.025 & 0.016 & 0.999 & 0.995 \\
Job Satisfaction & One Factors Model & 84.2 & 25 & 3.36 & 0.047 & 0.025 & 0.926 & 0.922 \\
\hline Job Performance & Two Factors Model & 94.3 & 30 & 3.14 & 0.097 & 0.074 & 0.823 & 0.789 \\
\hline
\end{tabular}

\section{Hypotheses Testing}

The current study has formulated two hypotheses, one is about the direct effects and other is about mediating effects. These two hypotheses were tested according to procedure mentioned in the previous data analysis section. In the first step a hypothesized model (M1) was built and was fitted into the data, as clear from fit indices in table 05. In next step, a Direct Effect Model by excluding mediator (M2) was built. In this model mediator variable was excluded, so that direct link between independent and dependent variables could be observed. The results for model fit were satisfactory and all of fit indices were within the acceptable range as clear from table 05. The latent independent variable of ethical leadership was positively associated with latent dependent variable of job performance $(\beta=0.012, p=0.001)$. In next step, a Direct Effect Model by excluding Job Performance (M3) was built. In this model the Job Performance was excluded.

The results for model fit were satisfactory and all of the fit indices were within the acceptable range as clear from table 05 . The standardized beta coefficient showed that there was positive association between mediator variable and independent variable $(\beta=0.108, p=0.001)$. In the third step, a Direct Effect Model by excluding ethical leadership (M4) was built. In this model, the independent variable of ethical leadership was excluded. The results for model fit were satisfactory and all of the fit indices were within acceptable range as clear from table 05. The mediator variable and dependent variable were positively associated with each other $(\beta=0.104$, $\mathrm{p}<$ 0.0.0001). On the basis of these three direct relationship models, first hypothesis was accepted.

\section{Table 5}

Structural Equation Modeling Results

\begin{tabular}{|c|c|c|c|c|c|c|c|}
\hline Models & $\mathrm{X} 2$ & $\mathrm{df}$ & $\mathrm{X} 2 / \mathrm{df}$ & RMSEA & RMR & CFI & GFI \\
\hline $\begin{array}{l}\text { Hypothesized Model (M1) } \\
\text { Direct Effect Model (M2) }\end{array}$ & 286 & 105 & 2.72 & 0.097 & 0.026 & 0.901 & 0.972 \\
\hline $\begin{array}{l}\text { Excluding Mediator } \\
\text { Direct Effect Model (M3) }\end{array}$ & 20.51 & 05 & 4.102 & 0.091 & 0.011 & 0.968 & 0.965 \\
\hline $\begin{array}{l}\text { Excluding Performance } \\
\text { Direct Effect Model (M4) }\end{array}$ & 230 & 77 & 2.981 & 0.096 & 0.027 & 0.901 & 0.867 \\
\hline $\begin{array}{l}\text { Excluding Ethical Leader } \\
\text { Hypothesized Model (M5) }\end{array}$ & 186 & 53 & 3.501 & 0.099 & 0.028 & 0.901 & 0.869 \\
\hline Constrained & 322 & 106 & 3.047 & 0.105 & 0.026 & 0.880 & 0.831 \\
\hline $\begin{array}{l}\text { Hypothesized Model (M6) } \\
\text { Non Constrained }\end{array}$ & 283 & 02 & 2.781 & 0.089 & 0.023 & 0.901 & 0.853 \\
\hline
\end{tabular}


Finally the Hypothesized Constrained Model by constraining A-B to zero (M5) was created, as clear from Figure 02. In this model initially relationship between independent and dependent variables was constrained to zero, due to which the model fit had decreased, as clear from the fit indices of (M5) in table 05. Therefore, in order to know whether partial or full mediation had occurred and to check whether model fit increases by non-constraining the M5 model, a non-constrained model (M6) was created, and then tested, as clear from table 05, figure 02. In the (M6) model, the model fit improved, however, the relationship between A-B-C paths was significant, consequently, the partial mediation had occurred (A-B, $\beta=0.104, p=0.001$; A-C, $\beta=0.506, p=0.001 ; B-C, \beta=0.409, p=0.131)$. In this way the second hypothesis was successfully accepted.

\section{Figure 2}

M6 Final Non-constrained Model with Standardized Beta or Path Coefficients

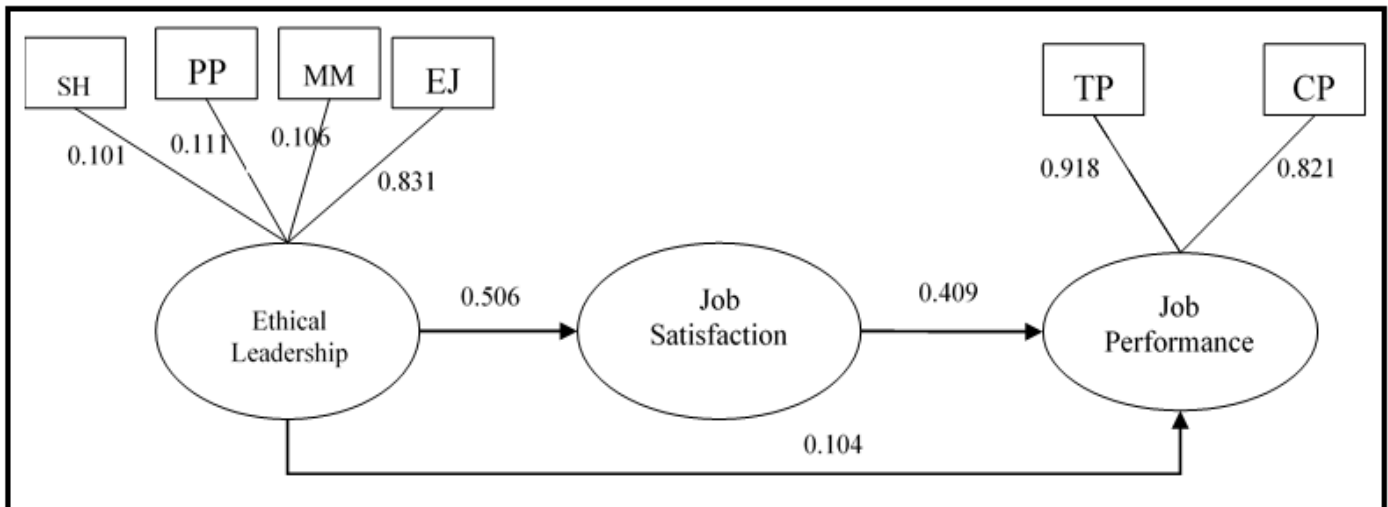

Note: $\mathrm{SH}=$ Safe Heaven; $\mathrm{PP}=$ Practice Preaching; $\mathrm{MM}=$ Moral Motivator; $\mathrm{EJ}=$ Ethics Justice; $\mathrm{TP}=$ Task Performance; $\mathrm{CP}=$ Contextual Performance

\section{DISCUSSION}

The current study had proposed that ethical leadership would have a positive relationship with the job performance. In the other words, a good ethical leader will boost up the performance of the employees. After running Structural Equation Modeling, the results revealed that all of the four dimensions (safe haven creator, practicing preacher, moral motivator and ethics of justice) of ethical leadership were positive associated with two dimensions of job performance ( task and contextual performance). The review of the existing literature shows that results of current study are in concurrence with results obtained from previous studies on the impact of ethical leadership on job performance. The review of existing literature contain studies in this regard, like, e.g., study by Budihastuti and Hamali (2016), which was conducted on the association of ethical leadership with teachers job performance working in Indonesian education institutions. The authors found that ethical leadership qualities like delegating authority, being mentor, lead meeting and make fair decisions were positively related with the job performance of teachers. Other similar as well as recent studies, e.g., studies by Adeoye (2020) and Grobler and Grobler (2021) were conducted on positive effects of the ethical leadership in the academia of western countries while Zamin and Hussin, (2021) and Sabir (2021) have conducted research on the 
ethical leadership and it link with commitment and job performance in different universities of Pakistan.

Moreover, another study by Yang and Wei (2017) was conducted to examine the influence of the ethical leadership on the employee's task performance in China. They found that the ethical leadership had a positive impact on task performance of Chinese employees. The findings of these previous research studies on relationship between ethical leadership and job performance show that ethical leadership has an influential role in boosting the employees' performance. The fact is that an ethical leader within the organization can guide the employees towards their goals, such leader can provide direction, can help them to get innovative idea, and can also help in times of crisis and disaster (Mulki \& Lassk, 2019). In this connection, this study further proposed that job satisfaction would mediate the relationship between ethical leadership and job performance. Consequently, tn the other words, the good ethical leader can better boost up the performance of the employees once the employees are more satisfied. Moreover, practices of a good ethical leader can cause employee satisfaction, which will ultimately help in boosting performance. Thus, after running structural equation modeling, the results revealed that the job satisfaction had partially mediated the relationship between the ethical leadership and the job performance.

The results of the current study regarding mediating role of job satisfaction are in concurrence with the results of previous studies on mediating role of job satisfaction in ethical leadership and job performance relationship. The review of existing literature has studies, like, e.g., study by Shafique et al., (2018) on the mediating role of job satisfaction in the ethical leadershipperformance association in Pakistan and found that job satisfaction had mediated the impact of ethical leadership on job performance. Similarly another study conducted in Malaysia by Jamaludin et al., (2014) on the mediating role of job satisfaction in the ethical leadership and organizational commitment link. This study revealed that job satisfaction had mediated the effect of ethical leadership on commitment, meaning that the Malaysian employees were more motivated and committed due to the good ethical leadership inside their organization. Finally study conducted in Vietnam by Khuong and Quoc (2016) on mediating role of job satisfaction in ethical leadership and job performance, found that job satisfaction had ethical leadership had played a significant role in improving the job performance. Ethical leadership had positive direct effects on the job performance and indirect impact on job performance through the job satisfaction. The researchers need to examine both direct as well as indirect link between two variables.

This study has yielded important research findings regarding the empirical testing of the some of the theories on ethical leadership and job performance within the context of Pakistan. This study has tested both the direct as well as indirect linkages between the ethical leadership and job performance. The findings of this study will be significant to employees that are working in universities of Pakistan, especially universities in southern KPK province of Pakistan. Findings will also be significant to researchers in field of Human Resource Management. The employees can get awareness about factors which can influence their job performance and satisfaction. The employees can also get awareness about the qualities of successful ethical leadership. On the other side, the researchers in the in field of Human Resource Management can get latest information about empirical testing of the construct of ethical leadership and its impacts on job performance in Pakistan, especially empirical testing of mediating role of job satisfaction. The findings of current study will be significant to administrator of universities, since they can 
understand dynamics of the ethical leadership and its effects on the job performance and job satisfaction.

In this way they can improve their own leadership qualities and can provide training to their employees. The administrator of universities can take measures to provide conducive working environment to its employees, thus that the employees are satisfied and can work in more productive and innovative way. At policy level, the policy makers in ministry of education and higher education commission can understand role of ethical leader in universities of Pakistan. They can work on appointing good leaders in universities of Pakistan and they can also work on formulating good work-related policies for development of the higher education sector as a whole.

\section{CONCLUSION}

The current study aimed at exploring the dynamic relationship between ethical leadership, job satisfaction and job performance of employees working in the higher education institutions of Pakistan. The findings of study revealed that there is both direct and indirect linkages between the ethical leadership and job performance of employees. Since it has been empirically proved through findings of this study that organizational outcomes of universities can be enhanced through positive behaviors that are adopted by the leaders of the universities, therefore, it has been concluded that ethical leadership is a very vital factor in the success of organizations. The universities in Pakistan should focus on appointing such administrators which have high level of ethical leadership qualities, and who can instill job satisfaction and boost up job performance of the employees. Moreover, the management of the Pakistani universities should take care of employees' satisfaction by providing them conducive working environment, so that employees feel satisfied. In this way, the ethical leaders would be able to instill the better employees' job satisfaction and higher work performance by playing the vital role in success of universities in Pakistan.

\section{Limitations \& Recommendations}

This study has certain limitation, on the basis of which some future research directions have been given. First, this study was cross sectional quantitative in nature and data was collected with questionnaire for one-point time, which can affect generalizability of the results. For this reason, future researchers should conduct longitudinal study by combining both qualitative and quantitative data. Such investigation will be helpful in knowing the changes in employee's performance with passage of time. Moreover, the ethical leadership concept could be more comprehensibly examined qualitatively. Second, this study has been conducted on a handful number of respondents taken from few universities; consequently, the future researchers can take broader sample from many universities. Third, this study has relied on subjective perceived data related to employees' performance, which may not be helpful in making any causative conclusion. Therefore, the future researchers should study employees' performance objectively by collecting objective data from official records of universities. Finally, this study has not examined the moderating role of training and career development in the nexus between ethical leadership and job performance, thus, the future researchers should work on examining such relationship.

\section{REFERENCES}

Adeoye, A. O. (2020). Ethical leadership, employees commitment and organizational 
effectiveness: A study of non-faculty members. Athens Journal of Business \& Economics, $6,1-12$.

Alonderiene, R., \& Majauskaite, M. (2016). Leadership style and job satisfaction in higher education institutions. International Journal of Educational Management, 30(1), 140164.

Amos, C., Zhang, L., \& Read, D. (2020). Hardworking as a heuristic for moral character: Why we attribute moral values to those who work hard and its implications. Journal of Business Ethics, 1-16.

Anwar, M., Khan, A., \& Sultan, K. (2020). The Barriers and Challenges Faced by Students in Online Education during Covid-19 Pandemic in Pakistan. Gomal University Journal of Research. 36 (1). 52-62.

Asrar-ul-Haq, M., \& Kuchinke, K. P. (2016). Impact of leadership styles on employees' attitude towards their leader and performance: Empirical evidence from Pakistani banks. Future Business Journal, 2(1), 54-64.

Avolio, B. J., Walumbwa, F. O., \& Weber, T. J. (2009). Leadership: Current theories, research, and future directions. Annual Review of Psychology, 6o, 421-449.

Barnett, D. (2017). Leadership and job satisfaction: Adjunct faculty at a for-profit university. International Journal of Psychology and Educational Studies, 4(3), 53-63.

Blanz, M. (2017). Employees' job satisfaction: A test of the job characteristics model among social work practitioners. Journal of Evidence-Informed Social Work, 14(1), 35-50.

Brown, M. E., Treviño, L. K., \& Harrison, D. A. (2005). Ethical leadership: A social learning perspective for construct development and testing. Organizational Behavior and Human Decision Processes, 97(2), 117-134.

Budihastuti, E. S., \& Hamali, A. Y. (2016). The Relationship Between Leadership And Teachers' Performance At State Vocational High SchoolL "X" Bandung. The Winners, 17(2), 77-89.

Campbell, J. P. (1990). Modeling the performance prediction problem in industrial and organizational psychology.

Cleveland, J. N., Huebner, L.-A., Anderson, K. J., \& Agbeke, D. V. (2019). Lifespan perspectives on job performance, performance appraisal/management and creative performance. In Work across the lifespan (pp. 291-321). Elsevier.

Dinh, J. E., Lord, R. G., Gardner, W. L., Meuser, J. D., Liden, R. C., \& Hu, J. (2014). Leadership theory and research in the new millennium: Current theoretical trends and changing perspectives. The Leadership Quarterly, 25(1), 36-62.

Dion, M. (2012). Are ethical theories relevant for ethical leadership? Leadership \& Organization Development Journal.

Djafar, H., Yunus, R., Pomalato, S. W. D. J., \& Rasid, R. (2021). Qualitative and Quantitative Paradigm Constellation In Educational Research Methodology. International Journal of Educational Research \& Social Sciences, 2(2), 339-345.

Gliem, J. A., \& Gliem, R. R. (2003). Calculating, interpreting, and reporting Cronbach's alpha reliability coefficient for Likert-type scales. Midwest Research-to-Practice Conference in Adult, Continuing, and Community ....

Goodman, S., \& Svyantek, D. J. (1999). Person-organization fit and contextual performance: Do shared values matter. Journal of Vocational Behavior, 55(2), 254-275.

Grobler, S., \& Grobler, A. (2021). Ethical leadership, person-organizational fit, and productive energy: a South African sectoral comparative study. Ethics \& Behavior, 31(1), 21-37.

Hair, J., Black, W., Babin, B., Anderson, R., \& Tatham, R. (2016). Multivariate data analysis (Vol. 7). Prentice hall Upper Saddle River, NJ. 
Halai, N. (2013). Quality of private universities in Pakistan: An analysis of higher education commission rankings 2012. International Journal of Educational Management, 27(7), $775-786$.

Heres. (2014). The Full Range Of Implicit Ethical Leadership Theories.

Herzberg, F., Mausner, B., \& Snyderman, B. B. (1993). The motivation to work (New ed.). New Brunswick, New Jersey: Transaction.

Hidayat, R., \& Budiatma, J. (2018). Education and job training on employee performance. International Journal of Social Sciences and Humanities, 2(1), 171-181.

Holmbeck, G. N. (1997). Toward terminological, conceptual, and statistical clarity in the study of mediators and moderators: Examples from the child-clinical and pediatric psychology literatures. Journal of Consulting and Clinical Psychology, 65(4), 599.

Huseman, R. C., Hatfield, J. D., \& Miles, E. W. (1987). A new perspective on equity theory: The equity sensitivity construct. Academy of Management Review, 12(2), 222-234.

Işik, A. N. (2020). Ethical leadership and school effectiveness: The mediating roles of affective commitment and job satisfaction. International Journal of Educational Leadership and Management, 8(1), 60-87.

Jamaludin, A., Hashim, R. A., \& Mahmood, R. (2014). Mediating effect of jo b satisfaction on transactional leaders and commitment to service quality i n malaysian universities.

Karuhanga, B. N. (2015). Evaluating implementation of strategic performance management practices in universities in Uganda. Measuring Business Excellence, 19(2), 42-56.

Kelidbari, H. R. R., Fadaei, M., \& Ebrahimi, P. (2016). The role of ethical leadership on employee performance in Guilan University of medical sciences. Procedia-Social and Behavioral Sciences, 230, 463-470.

Khan, A., \& Anwar, M. (2021). Higher Education in Peril: Challenges to Southeast Asian Academics. In Higher Education Challenges in South-East Asia (pp. 238-249). IGI Global.

Khokhar, A. M., \& Zia-ur-Rehman, M. (2017). Linking ethical leadership to employees' performance: Mediating role of organizational citizenship behavior and counterproductive work behavior. Pakistan Journal of Commerce and Social Sciences, 11(1), 222-251.

Khuong, M., \& Quoc, T. H. (2016). The effects of organizational justice and ethical leadership on employee performance in Binh Duong's Industrial Parks, Vietnam. Journal of Economics, Business and Management, 4(4), 327-333.

Kinsambwe, R. (2016). Leadership Styles and Performance of Academic Staff in Public Universities in Uganda. In Chaos, Complexity and Leadership 2014 (pp. 251-260). Springer.

Koopman, J., Scott, B. A., Matta, F. K., Conlon, D. E., \& Dennerlein, T. (2019). Ethical leadership as a substitute for justice enactment: An information-processing perspective. Journal of Applied Psychology, 104(9), 1103.

Koopmans, L., Bernaards, C. M., Hildebrandt, V. H., Schaufeli, W. B., de Vet Henrica, C. W., \& van der Beek, A. J. (2011). Conceptual frameworks of individual work performance: a systematic review. Journal of Occupational and Environmental Medicine, 53(8), 856866.

Körner, M., Wirtz, M. A., Bengel, J., \& Göritz, A. S. (2015). Relationship of organizational culture, teamwork and job satisfaction in interprofessional teams. BMC Health Services Research, 15(1), 243.

Langlois, L., Lapointe, C., Valois, P., \& de Leeuw, A. (2014). Development and validity of the 
ethical leadership questionnaire. Journal of Educational Administration, 52(3), 310331.

Lavrakas, P. J. (2008). Encyclopedia of Survey Research Methods. SAGE Publications.

Liu, J., Kwan, H. K., Fu, P. P., \& Mao, Y. (2013). Ethical leadership and job performance in C hina: The roles of workplace friendships and traditionality. Journal of Occupational and Organizational Psychology, 86(4), 564-584.

Malik, M. S., Awais, M., Timsal, A., \& Qureshi, U. H. (2011). Impact of Ethical Leadership on Employees' Performance: Moderating Role of Organizational Values. International Review of Management and Marketing, 7(3), 12-34.

Manzoor, F., Wei, L., Bányai, T., Nurunnabi, M., \& Subhan, Q. A. (2019). An examination of sustainable HRM practices on job performance: An application of training as moderator. Sustainability, 11(8), 2263.

Meng, Q., \& Wang, G. (2019). A research on sources of university faculty occupational stress: a Chinese case study. Psychology Research and Behavior Management, 11, 597-605.

Mohrman, K., Ma, W., \& Baker, D. (2008). The research university in transition: The emerging global model. Higher Education Policy, 21(1), 5-27.

Mozumder, N. A. (2018). A multilevel trust-based model of ethical public leadership. Journal of Business Ethics, 153(1), 167-184.

Mulki, J., \& Lassk, F. G. (2019). Joint impact of ethical climate and external work locus of control on job meaningfulness. Journal of Business Research, 99, 46-56.

O'Connell, W., \& Bligh, M. (2009). Emerging from ethical scandal: Can corruption really have a happy ending? Leadership, 5(2), 213-235.

Obicci, P. A. (2015). Effects of ethical leadership on employee performance in Uganda. Net Journal of Business Management, 3(1), 1-12.

Ofoegbu, F. O., \& Alonge, H. O. (2017). Effective University Leadership as Predictor of Academic Excellence in Southern Nigerian Universities. Journal of Education and Practice, 8(8), 111-116.

Okan, T., \& Akyüz, A. M. (2015). Exploring the Relationship between Ethical Leadership and Job Satisfaction with the Mediating Role of the Level of Loyalty to Supervisor. Business \& Economics Research Journal, 6(4).

Qazi, W., Raza, S. A., Jawaid, S. T., \& Karim, M. Z. A. (2018). Does expanding higher education reduce income inequality in emerging economy? Evidence from Pakistan. Studies in Higher Education, 43(2), 338-358.

Read, L. E. (2018). Elements of Libertarian Leadership: Notes on the Theory, Methods, and Practice of Freedom. Pickle Partners Publishing.

Rizwan, M., Zeeshan, C., \& Mahmood, S. (2017). The impact of perceived ethical leadership and organizational culture on job satisfaction with the mediating role of organizational commitment in private educational sector of Islamabad, Pakistan. Journal of Intercultural Management, 9(1), 75-100.

Sabir, S. (2021). A study on Ethical leadership perceptions and its impact on teachers commitment in Pakistan. International Journal of Educational Leadership and Management, 9(1), 28-53.

Sendjaya, S., Pekerti, A. A., Cooper, B. K., \& Zhu, C. J. (2019). Fostering organisational citizenship behaviour in Asia: The mediating roles of trust and job satisfaction. In Leading for High Performance in Asia, (pp. 1-18). Springer.

Shafique, I., Kalyar, M., \& Ahmad, B. (2018). The Nexus of Ethical Leadership, Job Performance, and Turnover Intention: The Mediating Role of Job Satisfaction. 
Interdisciplinary Description of Complex Systems: INDECS, 16(1), 71-87.

Shakeel, F., Kruyen, P. M., \& Van Thiel, S. (2019). Ethical leadership as process: A conceptual proposition. Public Integrity, 21(6), 613-624.

Smith, C., Organ, D. W., \& Near, J. P. (1983). Organizational citizenship behavior: Its nature and antecedents. Journal of Applied Psychology, 68(4), 653.

Tomkins, S. S. (1984). Affect theory. Approaches to Emotion, 163(163-195).

Torlak, N. G., \& Kuzey, C. (2019). Leadership, job satisfaction and performance links in private education institutes of Pakistan. International Journal of Productivity and Performance Management, 68(2), 276-295.

Udofia, D., \& Alexander, C. (2017). Leadership in the Health Sector: A Discourse of the Leadesrhip Model of Utilitarianism. Online Journal of Health Ethics, 13(1), 6.

Williams, L. J., \& Anderson, S. E. (1991). Job satisfaction and organizational commitment as predictors of organizational citizenship and in-role behaviors. Journal of Management, 17(3), 601-617.

Yang, Q., \& Wei, hua. (2018). The impact of ethical leadership on organizational citizenship behavior: The moderating role of workplace ostracism. Leadership \& Organization Development Journal, 39(1), 100-113.

Yang, Q., \& Wei, H. (2017). Ethical Leadership and Employee Task Performance: Examining Moderated Mediation Process. Management Decision, 55(7), 234-245.

Yuan, L., Tan, X., Huang, C., \& Zou, F. (2014). Mediating effect of job satisfaction on the relationship between emotional intelligence and perceived general health. Social Behavior and Personality: An International Journal, 42(7), 1057-1067.

Zaim, H., Demir, A., \& Budur, T. (2021). Ethical leadership, effectiveness and team performance: An Islamic perspective. Middle East Journal of Management, 8(1), 42-66.

Zamin, S. A., \& Hussin, F. (2021). Effect of Leadership Styles and Work Climate on Job Performance: A Mediating Role of Organizational Commitment among University Lecturers in Pakistan. Elementary Education Online, 20(2), 497-505.

Zhang, G., Zhong, J., \& Ozer, M. (2020). Status threat and ethical leadership: A power-dependence perspective. Journal of Business Ethics, 161(3), 665-685.

Zhu, W., Treviño, L. K., \& Zheng, X. (2016). Ethical leaders and their followers: The transmission of moral identity and moral attentiveness. Business Ethics Quarterly, 26(1), 95-115. 